Article

\title{
Catalytic Steam Reforming of Toluene as a Model Compound of Biomass Gasification Tar Using $\mathrm{Ni}-\mathrm{CeO}_{2} / \mathrm{SBA}-15$ Catalysts
}

\author{
Jun Tao ${ }^{1}$, Leiqiang Zhao ${ }^{1}$, Changqing Dong ${ }^{1}$, Qiang Lu ${ }^{1, *}$, Xiaoze Du ${ }^{2}$ and Erik Dahlquist ${ }^{3}$ \\ 1 National Engineering Laboratory for Biomass Power Generation Equipment, North China Electric \\ Power University, No.2 Beinong Road, Changping District, Beijing 102206, China; \\ E-Mails: firsttaojun@163.com (J.T.); zhaoleiqiang@126.com (L.Z.); cqdong1@163.com (C.D.) \\ 2 Key Laboratory of Condition Monitoring and Control for Power Plant Equipment, Ministry of \\ Education, North China Electric Power University, No.2 Beinong Road, Changping District, \\ Beijing 102206, China; E-Mail: duxz@ncepu.edu.cn \\ 3 School of Sustainable Development of Society and Technology, Mälardalen Univeristy, Västerås, \\ SE-721 23, Sweden; E-Mail: erik.dahlquist@mdh.se
}

* Author to whom correspondence should be addressed; E-Mail: qianglu@mail.ustc.edu.cn; Tel.: +86-10-6177-2063; Fax: +86-10-6177-2032 (ext. 801).

Received: 6 May 2013; in revised form: 16 June 2013 / Accepted: 27 June 2013 / Published: 4 July 2013

\begin{abstract}
Nickel supported on SBA-15 doped with $\mathrm{CeO}_{2}$ catalysts $\left(\mathrm{Ni}-\mathrm{CeO}_{2} / \mathrm{SBA}-15\right)$ was prepared, and used for steam reforming of toluene which was selected as a model compound of biomass gasification tar. A fixed-bed lab-scale set was designed and employed to evaluate the catalytic performances of the $\mathrm{Ni}-\mathrm{CeO}_{2} / \mathrm{SBA}-15$ catalysts. Experiments were performed to reveal the effects of several factors on the toluene conversion and product gas composition, including the reaction temperature, steam/carbon $(\mathrm{S} / \mathrm{C})$ ratio, and $\mathrm{CeO}_{2}$ loading content. Moreover, the catalysts were subjected to analysis of their carbon contents after the steam reforming experiments, as well as to test the catalytic stability over a long experimental period. The results indicated that the $\mathrm{Ni}-\mathrm{CeO}_{2} / \mathrm{SBA}-15$ catalysts exhibited promising capabilities on the toluene conversion, anti-coke deposition and catalytic stability. The toluene conversion reached as high as $98.9 \%$ at steam reforming temperature of $850{ }^{\circ} \mathrm{C}$ and $\mathrm{S} / \mathrm{C}$ ratio of 3 using the $\mathrm{Ni}-\mathrm{CeO}_{2}(3 \mathrm{wt} \%) / \mathrm{SBA}-15$ catalyst. Negligible coke formation was detected on the used catalyst. The gaseous products mainly consisted of $\mathrm{H}_{2}$ and $\mathrm{CO}$, together with a little $\mathrm{CO}_{2}$ and $\mathrm{CH}_{4}$.
\end{abstract}


Keywords: steam reforming; biomass gasification tar; toluene; $\mathrm{Ni}-\mathrm{CeO}_{2} / \mathrm{SBA}-15$

\section{Introduction}

The utilization of lignocellulosic biomass has gained attention in recent years [1-3]. Among the various conversion technologies, gasification is a promising one to convert solid biomass mainly into a gaseous product rich in $\mathrm{H}_{2}$ and $\mathrm{CO}$ which can be used as a gaseous fuel or a raw material for Fischer-Tropsch synthesis [4-6]. A major problem involved in the gasification process is the formation of tar which is a complex mixture of various organic compounds, especially aromatic compounds. Tars would bring many negative effects to the operation of the gasification equipment as well as the downstream gas utilization engines or turbines. Therefore, it is very essential to remove tars for the commercialization of the biomass gasification technique.

There are several methods to remove tars. One of them is catalytic steam reforming which can convert tar compounds in the presence of steam to permanent gases, with high energy recovery and minimal environmental pollution [7,8]. The key problem for catalytic steam reforming is the selection of the proper catalyst. Till now, various catalysts have been prepared and tested, mainly including the olivine and dolomite [9-11], Ni-based catalysts [12-14] and noble metal catalysts [15]. Among these catalysts, Ni-based catalysts were confirmed to be effective for tar reduction, due to the promising cracking capability of the $\mathrm{NiO} / \mathrm{Ni}$ [8,16-18]. For instance, Zhao et al. [19] prepared Ni/cordierite catalysts for steam reforming of toluene which was selected as a model tar compound. The results indicated that the toluene conversion would be enhanced with the increase of reforming temperature, reaching as high as $94.1 \%$ at $900{ }^{\circ} \mathrm{C}$. Zhang et al. [20] prepared Ni/olivine catalysts doped with $\mathrm{CeO}_{2}$ for steam reforming of model tar compounds (benzene and toluene), and found that the catalysts were effective in terms of both catalytic activity and anti-coke deposition performances.

However, during the catalytic process, the Ni-based catalysts would deactivate very rapidly, mainly resulting from the coke deposition. Hence, it is essential to improve the anti-coke deposition performances of the Ni-based catalysts. In this study, nickel supported on SBA-15 doped with $\mathrm{CeO}_{2}$ (Ni-CeO $/$ SBA-15) catalysts were prepared for steam reforming of biomass gasification tars. The $\mathrm{CeO}_{2}$ was selected as the catalyst promoter, because it is preliminarily confirmed to be effective to prevent coke deposition and stabilize the catalysts, due to the strong metal support interaction of the $\mathrm{Ni}-\mathrm{CeO}_{2}$ system [20]. The $\mathrm{CeO}_{2}$ can accelerate the reaction of steam and absorbed species on nickel surface near the boundary area, so that carbon deposited on the surface can be quickly converted to gaseous products, preventing its accumulation. Moreover, SBA-15 was selected as the catalyst support, because it is a highly ordered mesoporous material which has much larger pore size $(3-30 \mathrm{~nm})$ than those of traditional microporous catalysts $(<2 \mathrm{~nm})$ [21-23]. The large pore size makes the mesoporous SBA-15 very promising to convert large molecule compounds, since the traditional microporous catalysts are unable to treat the large molecules (including tars). The SBA-15 also has good thermal and hydrothermal stability, further making it a promising support for various catalysts [24,25].

In this study, a lab-scale setup was designed and established for steam reforming experiments using the $\mathrm{Ni}-\mathrm{CeO}_{2} / \mathrm{SBA}-15$ catalysts. To better understand the catalytic performances of the 
$\mathrm{Ni}-\mathrm{CeO}_{2} / \mathrm{SBA}-15$ catalysts, toluene was selected as the model tar compound for experiments, because it is a major and stable tar compound formed in the high temperature gasification process. Experiments were performed to reveal the effects of the reaction temperature, $\mathrm{S} / \mathrm{C}$ ratio, and $\mathrm{CeO}_{2}$ loading content on the toluene conversion and product distribution.

\section{Experimental}

\subsection{Catalyst Preparation}

The SBA-15 was synthesized by the sol-gel method [21]. Typically, a homogeneous mixture composed of block copolymer surfactant (Pluronic $\mathrm{P} 123 ; \mathrm{PEO}_{20} \mathrm{PPO}_{70} \mathrm{PEO}_{20}$ ) and tetraethyl orthosilicate (TEOS) in hydrochloric acid was stirred at $40{ }^{\circ} \mathrm{C}$ for $24 \mathrm{~h}$ and then crystallized in a Teflon-lined autoclave at $100{ }^{\circ} \mathrm{C}$ for 2 days. The resultant solid was filtered, washed and dried. After calcination in air at $550{ }^{\circ} \mathrm{C}$ for $4 \mathrm{~h}$, the white SBA-15 powders were obtained and used as the catalyst supports for the preparation of the $\mathrm{Ni} / \mathrm{SBA}-15$ and $\mathrm{Ni}-\mathrm{CeO}_{2} / \mathrm{SBA}-15$ catalysts.

The Ni/SBA-15 and $\mathrm{Ni}-\mathrm{CeO}_{2} / \mathrm{SBA}-15$ catalysts were prepared by one step incipient wetness impregnation method [26]. To prepare the Ni-SBA-15 catalyst, $1.5 \mathrm{~g}$ nickel nitrate hexahydrate was firstly dissolved in $53 \mathrm{~mL}$ deionized water. Afterwards, $9.7 \mathrm{~g} \mathrm{SBA}-15$ was added to the above solution with ultrasonic treatment for $12 \mathrm{~h}$. The mixture was then dried at $105{ }^{\circ} \mathrm{C}$ in air for $12 \mathrm{~h}$. To prepare the $\mathrm{Ni}-\mathrm{CeO}_{2} / \mathrm{SBA}-15$ catalysts, $1.5 \mathrm{~g}$ nickel nitrate hexahydrate and certain amount of cerium nitrate hexahydrate $(0.3 \mathrm{~g}$ or $0.8 \mathrm{~g})$ were dissolved in certain amount of de-ionized water $(53 \mathrm{~mL}$ or $52 \mathrm{~mL})$, followed with the addition of certain amount of SBA-15 (9.6 g or 9.4 g) with ultrasonic treatment for $12 \mathrm{~h}$. The mixture was then dried at $105^{\circ} \mathrm{C}$ in air for $12 \mathrm{~h}$. The above resultant solids after drying were not calcined in air, but directly calcined in the mixture of nitrogen and hydrogen before catalytic activity tests, because calcination in air prior to the reduction step would be detrimental to obtain high reducibility, metal surface area, and metal dispersion of the Ni-based catalysts [27]. The nickel loading for all the catalysts was fixed at $3 \mathrm{wt} \%$ and the $\mathrm{CeO}_{2}$ loading was $0 \mathrm{wt} \%, 1 \mathrm{wt} \%$ and $3 \mathrm{wt} \%$, respectively.

\subsection{Catalyst Characterization}

Nitrogen adsorption and desorption isotherms of the catalysts were obtained at $77 \mathrm{~K}$ on the Quantachrome Autosorb-iQ physical adsorption instrument. Specific surface area and pore volume were calculated using Brunauer-Emmett-Teller (BET) equation and Barrett-Joyner-Halenda (BJH) method, respectively. The crystalline structures of the catalysts were assessed on a Rigaku Rotaflex diffractometer, using the $\mathrm{Cu} \mathrm{K} \alpha$ radiation $(\lambda=0.15406 \mathrm{~nm})$. Small-angle and wide-angle XRD patterns were measured over the $2 \theta$ range of $0.9 \sim 6^{\circ}$ and $10 \sim 80^{\circ}$. Moreover, after catalytic steam reforming experiments, the carbon contents of the catalysts were determined by a Vario Macro Cube Elemental Analyzer.

\subsection{Catalytic Steam Reforming Experiments}

A lab-scale experimental setup was designed and used for steam reforming of toluene, as shown in Figure 1. The setup mainly consisted of a syringe pump, a peristaltic pump, an upper quartz reactor, a bottom quartz reactor, an ice-cooled condenser, and an on-line gas analyzer (INFICON 3000 Micro 
gas chromatograph; INFICON, East Syracuse, NY, USA). The syringe pump and peristaltic pump were used to inject the liquid toluene and water which were then heated and evaporated in the upper quartz reactor (i.d. $15 \mathrm{~mm}$ ). The bottom reactor (i.d. $15 \mathrm{~mm}$ ) was used for steam reforming of the toluene, and $0.5 \mathrm{~g}$ uncalcined catalyst was filled in it and placed above some quartz wool at the uniform temperature zone. The upper and bottom quartz reactors were vertically positioned in two separate heating furnaces which were used to heat the two reactors. The temperatures of the two reactors were monitored by thermocouples.

Figure 1. Schematic of the toluene steam reforming set.

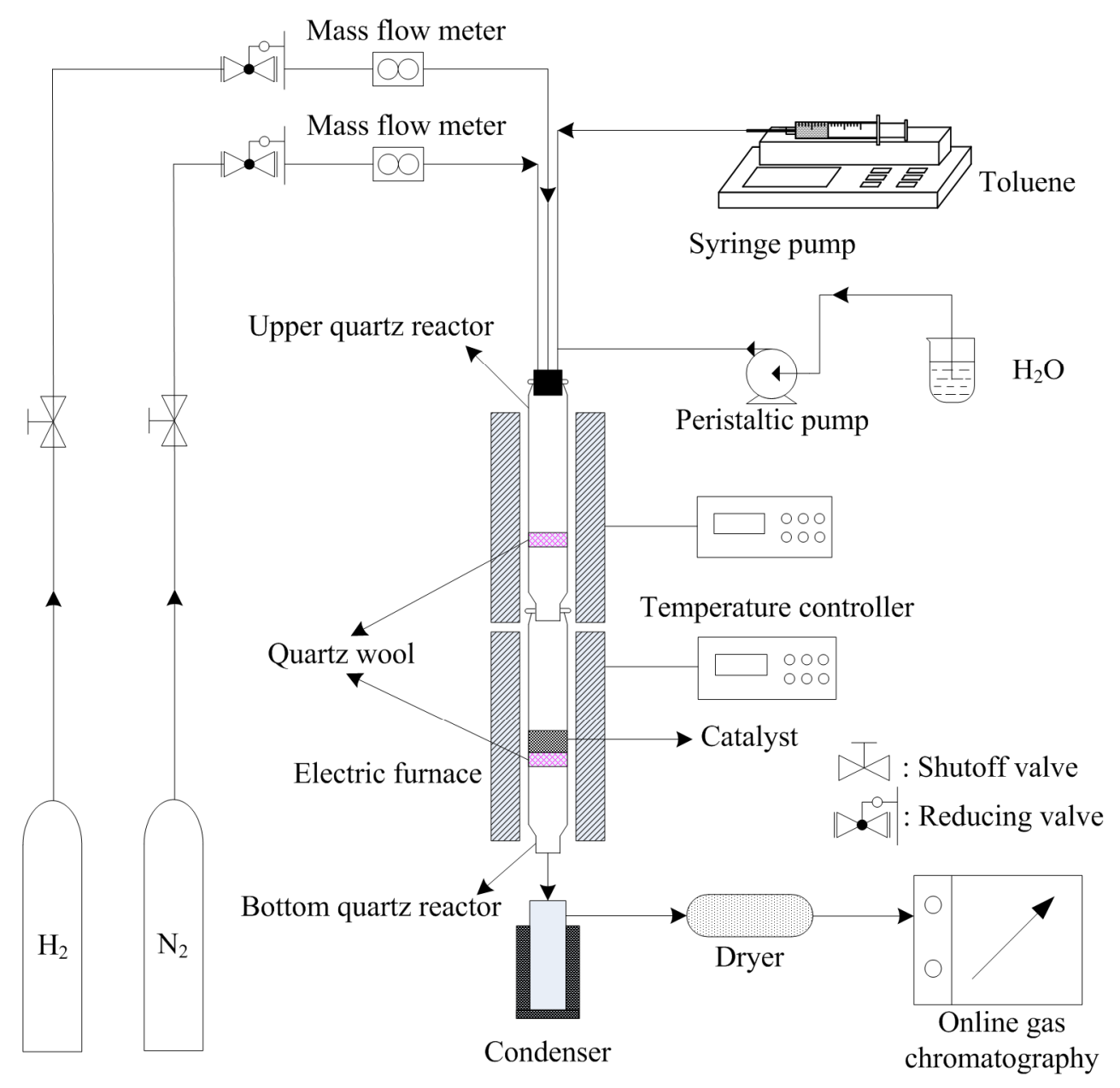

During the experiments, before the injection of the toluene and water, the catalyst was firstly calcined in the mixture of $50 \mathrm{vol} \% \mathrm{H}_{2}$ and $50 \mathrm{vol} \% \mathrm{~N}_{2}$ with the flow rate of $120 \mathrm{~mL} / \mathrm{min}$. The calcination was programmed from room temperature to $850{ }^{\circ} \mathrm{C}$ at the heating rate of $2{ }^{\circ} \mathrm{C} / \mathrm{min}$, and then held at $850{ }^{\circ} \mathrm{C}$ for $6 \mathrm{~h}$, to obtain the Ni/SBA-15 or Ni-CeO $/ \mathrm{SBA}-15$ catalyst. After the calcination, only $\mathrm{N}_{2}$ was used as the carrier gas for the steam reforming experiments. Toluene and water were injected to the upper quartz reactor which was heated to $300{ }^{\circ} \mathrm{C}$. The feeding rates of the $\mathrm{N}_{2}(\mathrm{~g}), \mathrm{H}_{2} \mathrm{O}(\mathrm{g})$ and toluene $(\mathrm{g})$, corresponding to the gaseous state at $25{ }^{\circ} \mathrm{C}$, were $29.7-40.8 \mathrm{~mL} / \mathrm{min}$, $7.4-18.5 \mathrm{~mL} / \mathrm{min}$ and $0.53 \mathrm{~mL} / \mathrm{min}$, respectively. The concentration of the toluene in the gas flow was fixed at $45 \mathrm{~g} / \mathrm{Nm}^{3}$ (1.1 vol.\%), in order to perform catalytic steam reforming experiments under severe conditions [28]. The $\mathrm{S} / \mathrm{C}$ ratio was in the range of $2-5$. The space time $\left(\mathrm{w}_{\text {cat }} / \mathrm{F}_{\text {toluene }}\right)$ at $25^{\circ} \mathrm{C}$, defined 
in terms of the catalyst weight divided to the volumetric flow rate of the toluene vapor, was $16 \mathrm{~kg}_{\text {cat }} \mathrm{h} / \mathrm{m}^{3}$ [29]. The nitrogen flow was controlled by a mass flowmeter and adjusted according to the $\mathrm{H}_{2} \mathrm{O}$ (g) content in the feeding mixture to keep the constant space time. The catalytic temperature was ranged from $700{ }^{\circ} \mathrm{C}$ to $850{ }^{\circ} \mathrm{C}$, similar as the practical gasifier. The effluent gases from the reactor were condensed in the ice-cooled condenser to collect the un-reacted toluene and water. The non-condensable gases were then dried by the $\mathrm{CaCl}_{2}$ column, and analyzed by the INFICON 3000 Micro gas chromatograph which was equipped with four detection modules, to measure the $\mathrm{H}_{2}$, $\mathrm{CO}, \mathrm{CO}_{2}, \mathrm{~N}_{2}$ and $\mathrm{C}_{1}-\mathrm{C}_{3}$ hydrocarbons. Each gas analysis was completed in $2.8 \mathrm{~min}$. Each steam reforming experiment lasted for $4 \mathrm{~h}$, resulting in around 85 measurements for each test. After the $4 \mathrm{~h}$ experiment, the injection of toluene and water was firstly stopped while nitrogen was still fed to cool down the catalyst to room temperature, preventing the catalyst being oxidized by the oxygen in air. Finally, the used catalyst was collected and subjected to further characterization.

\subsection{Data Analysis}

The $\mathrm{H}_{2}, \mathrm{CO}, \mathrm{CO}_{2}, \mathrm{CH}_{4}$ and $\mathrm{N}_{2}$ were detected in each gas analysis, and their contents were determined, while the $\mathrm{C}_{2}-\mathrm{C}_{3}$ hydrocarbons were not detected. For each steam reforming test, the average values of the $\mathrm{H}_{2}, \mathrm{CO}, \mathrm{CO}_{2}$ and $\mathrm{CH}_{4}$ contents from the 85 measurements were calculated. It is note that the nitrogen flow rate was fixed during each steam reforming test, and thus, based on the calculated average $\mathrm{N}_{2}$ content, it is able to calculate the yields of the $\mathrm{H}_{2}, \mathrm{CO}, \mathrm{CO}_{2}$ and $\mathrm{CH}_{4}$ in each experiment.

Based on the gaseous products, the toluene conversion $\left(\mathrm{X}_{\mathrm{C} 7 \mathrm{H} 8}\right)$ could be calculated according to Equation (1), which was defined in terms of the carbon in the gas products $\left(\mathrm{CO}, \mathrm{CO}_{2}, \mathrm{CH}_{4}\right)$ divided to the carbon in the toluene. The hydrogen content $\left(\mathrm{V} \%\left(\mathrm{H}_{2}\right)\right)$ was calculated according to Equation (2), and the contents of the other gases were calculated in the same way:

$$
\begin{gathered}
\mathrm{X}_{\mathrm{C} 7 \mathrm{H} 8}(\mathrm{~mol} \%)=\frac{\mathrm{F}_{\mathrm{CO}, \text { out }}+\mathrm{F}_{\mathrm{CO} 2 \text {,out }}+\mathrm{F}_{\mathrm{CH} 4 \text {,out }}}{7 \mathrm{~F}_{\mathrm{C} 7 \mathrm{H} 8 \text {,in }}} \times 100 \\
\mathrm{~V} \%\left(\mathrm{H}_{2}\right)=\frac{\mathrm{H}_{2}}{\mathrm{H}_{2}+\mathrm{CO}+\mathrm{CO}_{2}+\mathrm{CH}_{4}} \times 100
\end{gathered}
$$

\section{Results and Discussion}

\subsection{Catalyst Characterization}

The $\mathrm{N}_{2}$ adsorption/desorption isotherms of the SBA-15, Ni/SBA-15 and Ni-CeO $/$ /SBA- 15 catalysts are shown in Figure 2. The SBA-15 exhibited a typical irreversible type IV adsorption isotherm with a standard H1 hysteresis loop, and a sharp inflection at the relative pressure (p/p0) of 0.58 , implying this material had regular mesoporous channels. The Ni/SBA-15 and Ni-CeO $/ 2 / \mathrm{SBA}-15$ catalysts showed similar isotherms as the SBA-15, indicating that they retained the regular mesoporous structure of the parent SBA-15.

The textural properties of the catalysts are listed in Table 1 . The Ni/SBA-15 and Ni-CeO $/ \mathrm{SBA}-15$ catalysts had lower surface areas, smaller pore volumes and average pore diameters than the SBA-15, which should be due to the occupation of the $\mathrm{Ni}$ and $\mathrm{CeO}_{2}$ particles in the pore channels. Nevertheless, 
the two $\mathrm{Ni}-\mathrm{CeO}_{2} / \mathrm{SBA}-15$ catalysts possessed better textural properties than the Ni/SBA-15 catalyst, which might be due to the better nickel dispersion and smaller nickel particle sizes in the presence of the $\mathrm{CeO}_{2}$, as has been previously reported [30].

Figure 2. $\mathrm{N}_{2}$ adsorption/desorption isotherms with $\mathrm{BJH}$ pore size distribution analysis.

(a) SBA-15; (b) Ni/SBA-15; (c) Ni-CeO $2(1 \mathrm{wt} \%) / \mathrm{SBA}-15$; and (d) $\mathrm{Ni}_{-}-\mathrm{CeO}_{2}(3 \mathrm{wt} \%$ )/SBA-15.

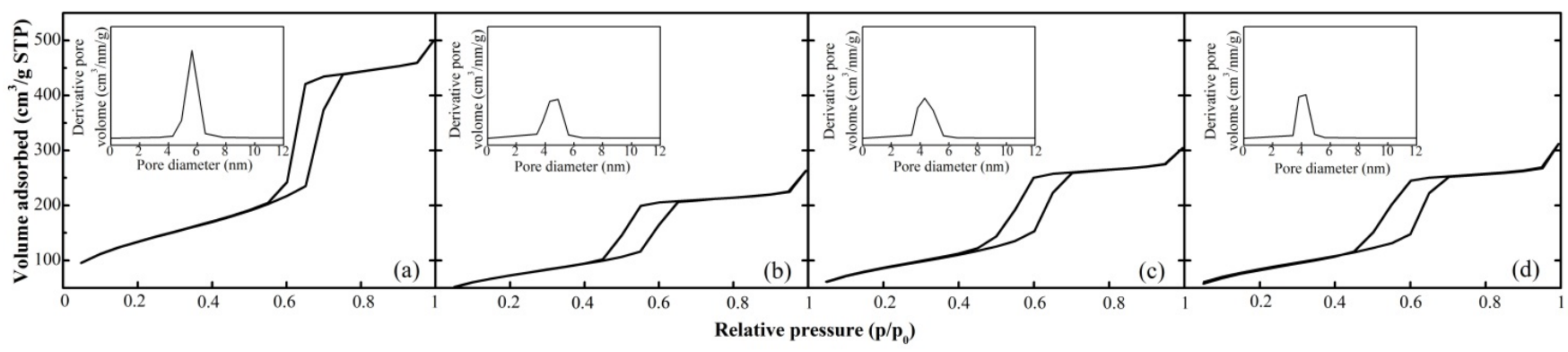

Table 1. Textural properties of the catalysts.

\begin{tabular}{cccc}
\hline Sample & BET Surface area $\left(\mathbf{m}^{2} / \mathbf{g}\right)$ & Pore volume $\left(\mathbf{c m}^{\mathbf{3}} / \mathbf{g}\right)$ & Average pore diameter $(\mathbf{n m})$ \\
\hline $\mathrm{SBA}-15$ & 476.4 & 0.76 & 5.63 \\
$\mathrm{Ni} / \mathrm{SBA}-15$ & 261.1 & 0.43 & 4.31 \\
$\mathrm{Ni}-\mathrm{CeO}_{2}(1 \mathrm{wt} \%) / \mathrm{SBA}-15$ & 301.6 & 0.48 & 4.32 \\
$\mathrm{Ni}-\mathrm{CeO}_{2}(3 \mathrm{wt} \%) / \mathrm{SBA}-15$ & 307.7 & 0.51 & 4.89 \\
\hline
\end{tabular}

Figure 3 gives the small-angle XRD patterns of the catalysts. The SBA-15 displayed an intense peak and two weak peaks for the mesoporous silica (100), (110) and (200) planes, respectively. This pattern indicated a 2D hexagonal mesostructure with space group p6 mm, matched well with the pattern reported for SBA-15 [21]. Similar diffraction peaks were observed for the Ni/SBA-15 and $\mathrm{Ni}-\mathrm{CeO}_{2} / \mathrm{SBA}-15$ catalysts, but these peaks were shifted to higher $2 \theta$ values, which might be due to the incorporation of the $\mathrm{Ni}$ and $\mathrm{CeO}_{2}$ on the SBA-15 [31]. Moreover, the intensities of the diffraction peaks were decreased, which might be attributed to the partial degradation of the hexagonal arrangement of SBA-15 pores [32] or the dilution of the silica by the nickel which has a higher absorption factor of X-rays than the silicon [33].

Figure 4 gives the wide-angle XRD patterns of the catalysts. The broad diffraction peak at about $2 \theta=23^{\circ}$ was attributed to the amorphous $\mathrm{SiO}_{2}$ [22]. The diffraction peaks at $2 \theta$ of $44.5^{\circ}$ and $51.8^{\circ}$ were assigned as the characteristic peaks of metallic nickel, JCPDS database (No. 01-1258) [30]. It is seen that in the presence of the $\mathrm{CeO}_{2}$, these peaks were broadened and their intensities were decreased, indicating the improved dispersion of the metallic phase. The crystalline size of the $\mathrm{Ni}^{0}$ phase, calculated according to the Scherrer equation from the characteristic peak at $44.5^{\circ}$, was reduced from $8.4 \mathrm{~nm}$ for the Ni/SBA-15 catalyst to $4.9 \mathrm{~nm}$ for the $\mathrm{Ni}-\mathrm{CeO}_{2}(3 \mathrm{wt} \%) / \mathrm{SBA}-15$ catalyst. The above results confirmed that the $\mathrm{CeO}_{2}$ could promote the dispersion of the Ni particles, agreed with previous studies $[25,30]$. This fact should be at least partly responsible for the better textural properties of the $\mathrm{Ni}-\mathrm{CeO}_{2} / \mathrm{SBA}-15$ catalysts than the $\mathrm{Ni} / \mathrm{SBA}-15$ catalyst. 
Figure 3. Small-angle XRD patterns of the catalysts. (a) SBA-15; (b) Ni/SBA-15; (c) $\mathrm{Ni}-\mathrm{CeO}_{2}(1 \mathrm{wt} \%) / \mathrm{SBA}-15$; and (d) $\mathrm{Ni}-\mathrm{CeO}_{2}(3 \mathrm{wt} \%) / \mathrm{SBA}-15$.

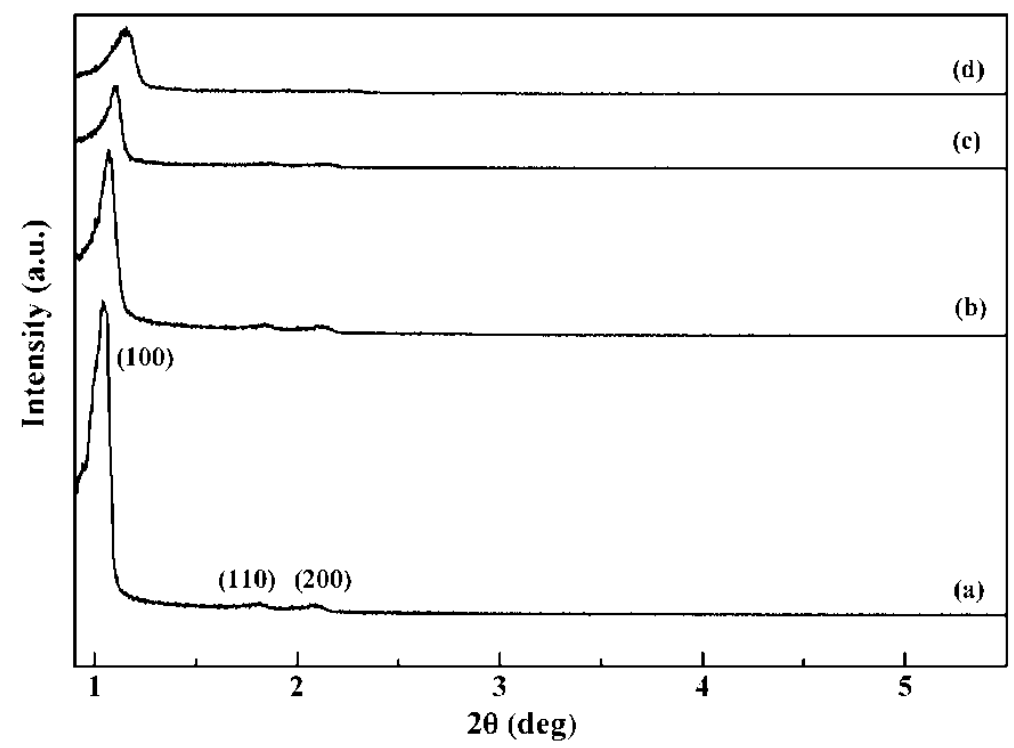

Figure 4. Wide-angle XRD patterns of the catalysts. (a) SBA-15; (b) Ni/SBA-15; (c) $\mathrm{Ni}-\mathrm{CeO}_{2}(1 \mathrm{wt} \%) / \mathrm{SBA}-15$; and (d) $\mathrm{Ni}-\mathrm{CeO}_{2}(3 \mathrm{wt} \%) / \mathrm{SBA}-15$.

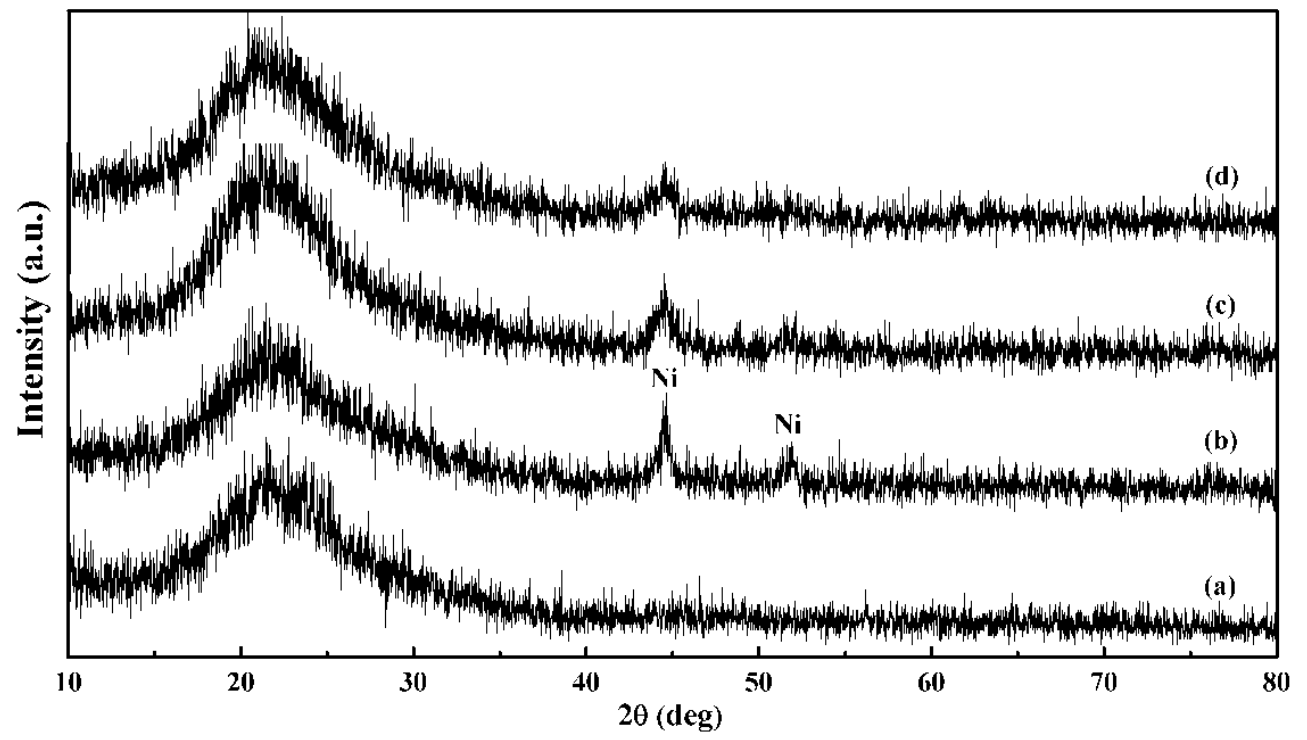

\subsection{Effects of Catalytic Temperature and $\mathrm{CeO}_{2}$ Loading Content on the Steam Reforming of Toluene}

Figure 5 illustrates the effects of catalytic temperatures on the steam reforming of toluene over different catalysts in the temperature range of $700-850{ }^{\circ} \mathrm{C}$ with the $\mathrm{S} / \mathrm{C}$ ratio of 3 . No catalyst deactivation was observed during the $4 \mathrm{~h}$ test for either catalyst. According to Figure 5, the toluene conversion was enhanced with an increase in the temperature and the $\mathrm{CeO}_{2}$ loading content. The highest toluene conversion reached as high as $98.9 \%$ at $850{ }^{\circ} \mathrm{C}$ using the $\mathrm{Ni}-\mathrm{CeO}_{2}(3 \mathrm{wt} \%) / \mathrm{SBA}-15$ catalyst. The results clearly indicated the $\mathrm{Ni}-\mathrm{CeO}_{2} / \mathrm{SBA}-15$ catalyst had promising catalytic capability to convert the toluene, and the $\mathrm{CeO}_{2}$ loading was capable to promote the catalytic activity. 
Figure 5. Effects of reaction temperatures on the toluene conversion and the gas composition. (a) Ni/SBA-15; (b) $\mathrm{Ni}-\mathrm{CeO}_{2}(1 \mathrm{wt} \%) / \mathrm{SBA}-15$; and (c) $\mathrm{Ni}^{-\mathrm{CeO}_{2}}(3 \mathrm{wt} \%) / \mathrm{SBA}-15$.

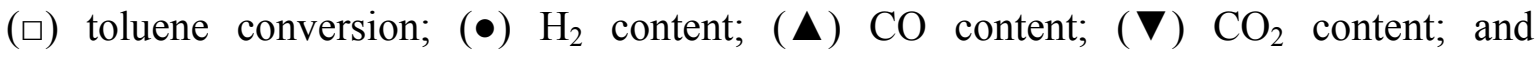
(४) $\mathrm{CH}_{4}$ content.

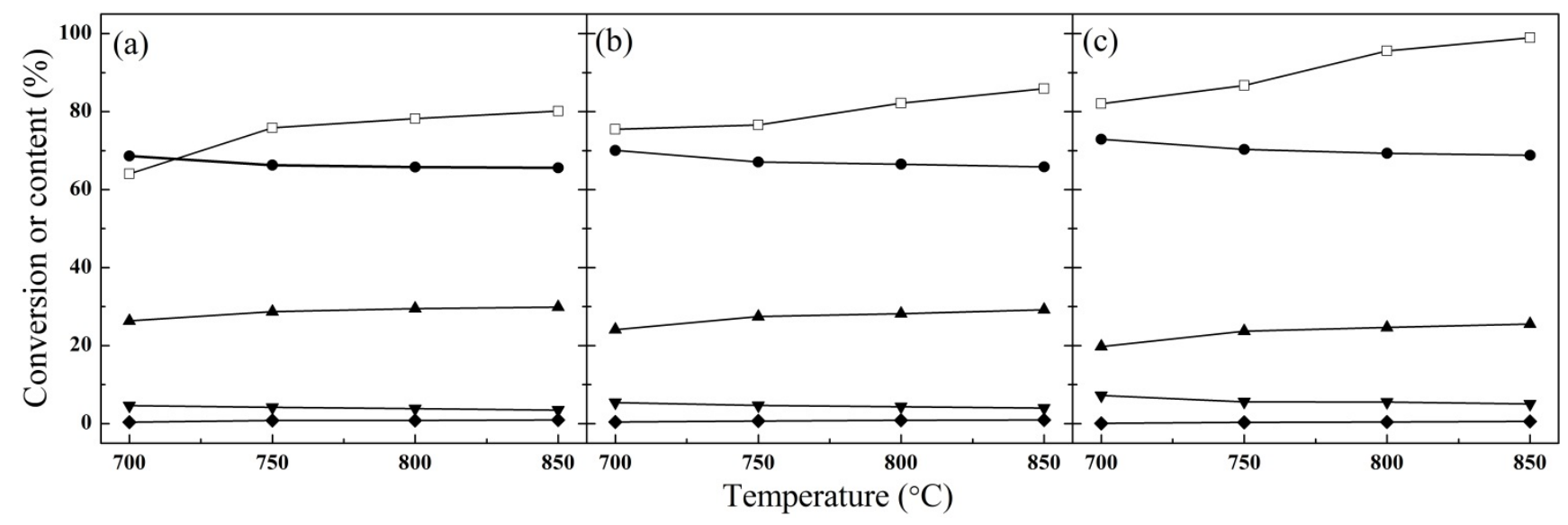

The steam reforming of toluene generated the $\mathrm{H}_{2}$ and $\mathrm{CO}$ as the major products, together with $\mathrm{CO}_{2}$ and $\mathrm{CH}_{4}$ as the minor products. According to Figure 5, the contents of these gas products were remarkably affected by the catalytic temperature, but not greatly influenced by the $\mathrm{CeO}_{2}$ loading content. The $\mathrm{CO}$ content was increased monotonically along with the catalytic temperature, from $19.8 \%$ at $700{ }^{\circ} \mathrm{C}$ to $25.5 \%$ at $850{ }^{\circ} \mathrm{C}$ using the $\mathrm{Ni}-\mathrm{CeO}_{2}(3 \mathrm{wt} \%) / \mathrm{SBA}-15$ catalyst. The $\mathrm{H}_{2}$ and $\mathrm{CO}_{2}$ contents were changed oppositely, decreased from $72.9 \%$ and $7.3 \%$ at $700{ }^{\circ} \mathrm{C}$ to $68.8 \%$ and $5.0 \%$ at $850{ }^{\circ} \mathrm{C}$, respectively. This might be attributed to the temperature improved reverse water gas shift reaction $\left(\mathrm{CO}+\mathrm{H}_{2} \mathrm{O} \leftrightarrow \mathrm{H}_{2}+\mathrm{CO}_{2}\right)$. Due to the exothermal nature of the water gas shift reaction, the increase of temperature would favor the formation of $\mathrm{CO}$ on the expense of $\mathrm{H}_{2}$ and $\mathrm{CO}_{2}$ [19]. The $\mathrm{CH}_{4}$ content was below $1.0 \%$, and almost kept constant under different catalytic temperatures.

The catalysts after $4 \mathrm{~h}$ catalytic steam reforming tests were analyzed to measure their carbon contents, and the results are shown in Table 2. It is seen that the carbon content was gradually decreased along with the catalytic temperature and the $\mathrm{CeO}_{2}$ loading content. The least carbon content was observed for the $\mathrm{Ni}-\mathrm{CeO}_{2}(3 \mathrm{wt} \%) / \mathrm{SBA}-15$ catalyst under the catalytic temperature of $850{ }^{\circ} \mathrm{C}$, with the value of only $0.01 \mathrm{wt} \%$, which was negligible. The above results clearly indicated that the presence of the $\mathrm{CeO}_{2}$ could improve the anti-coke deposition performances of the catalysts.

Table 2. Carbon contents of the three used catalysts under different reaction temperatures.

\begin{tabular}{ccccc}
\hline \multirow{2}{*}{ Sample } & \multicolumn{4}{c}{ Carbon content under different temperatures (wt\%) } \\
\cline { 2 - 5 } & $700{ }^{\circ} \mathrm{C}$ & $750{ }^{\circ} \mathrm{C}$ & $800{ }^{\circ} \mathrm{C}$ & $850{ }^{\circ} \mathrm{C}$ \\
\hline $\mathrm{Ni} / \mathrm{SBA}-15$ & 0.31 & 0.28 & 0.25 & 0.21 \\
$\mathrm{Ni}-\mathrm{CeO}_{2}(1 \mathrm{wt} \%) / \mathrm{SBA}-15$ & 0.12 & 0.11 & 0.05 & 0.02 \\
$\mathrm{Ni}-\mathrm{CeO}_{2}(3 \mathrm{wt} \%) / \mathrm{SBA}-15$ & 0.09 & 0.08 & 0.05 & 0.01 \\
\hline
\end{tabular}

It was previously reported that an active catalyst for steam reforming of tar compounds should be effective to cleavage the $\mathrm{C}-\mathrm{C}$ bond and also promote the water gas shift reaction [34]. Although the metal $\mathrm{Ni}$ was able to catalyze the $\mathrm{C}-\mathrm{C}$ bond cleavage, it was not very capable to promote the water gas 
shift reaction and to resist coke deposition. The $\mathrm{CeO}_{2}$ was known for its oxygen storage and release ability [35], and thus, could be used as the catalytic promoter to enhance the anti-coke deposition performances of the catalysts. Therefore, the Ni-CeO $2 / \mathrm{SBA}-15$ catalysts had more promising effects than the Ni/SBA-15 catalyst to convert toluene and to resist coke deposition.

\subsection{Effects of the S/C Ratio on the Steam Reforming of Toluene}

Figure 6 shows the effects of $\mathrm{S} / \mathrm{C}$ ratios on the steam reforming of toluene using the three catalysts at $850{ }^{\circ} \mathrm{C}$. The $\mathrm{S} / \mathrm{C}$ ratio had profound effects on the toluene conversion and the gas composition. According to Figure 6, with the increase of the S/C ratio from 2 to 5, the toluene conversion was firstly increased and then decreased, and the maximal toluene conversion was obtained at the $\mathrm{S} / \mathrm{C}$ ratio of 3 . In regard to the gas products, the $\mathrm{H}_{2}$ and $\mathrm{CO}_{2}$ contents were steadily increased along with the $\mathrm{S} / \mathrm{C}$ ratio, while the $\mathrm{CO}$ and $\mathrm{CH}_{4}$ contents were monotonically decreased. This phenomenon might be explained by the toluene steam reforming reaction $\left(\mathrm{C}_{7} \mathrm{H}_{8}+14 \mathrm{H}_{2} \mathrm{O} \rightarrow 7 \mathrm{CO}_{2}+18 \mathrm{H}_{2}\right)$ and water gas shift reaction. During the steam reforming process, the toluene and water molecules were absorbed on the catalyst surface, reacting to form $\mathrm{CO}$ or $\mathrm{CO}_{2}$. At the high $\mathrm{S} / \mathrm{C}$ ratio, most of the active sites of the catalyst surface would be occupied by the $\mathrm{H}_{2} \mathrm{O}$ molecules [34], resulting in the decreased adsorption and conversion of the toluene. Nevertheless, the high water concentration would promote the water gas shift reaction towards the formation of the $\mathrm{H}_{2}$ and $\mathrm{CO}_{2}$. Based on Figure 6 , the $\mathrm{S} / \mathrm{C}$ ratio of 3 was the optimal condition for the toluene conversion and product gas composition.

Figure 6. Effects of $\mathrm{S} / \mathrm{C}$ rations on the toluene conversion and the gas composition.

(a) $\mathrm{Ni} / \mathrm{SBA}-15$; (b) $\mathrm{Ni}-\mathrm{CeO}_{2}(1 \mathrm{wt} \%) / \mathrm{SBA}-15$; and (c) $\mathrm{Ni}_{-}-\mathrm{CeO}_{2}(3 \mathrm{wt} \%) / \mathrm{SBA}-15$.

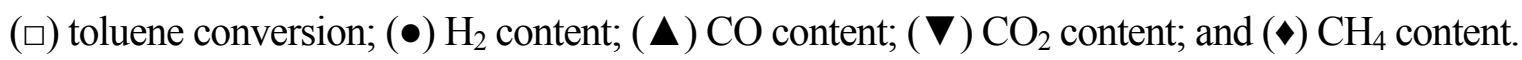

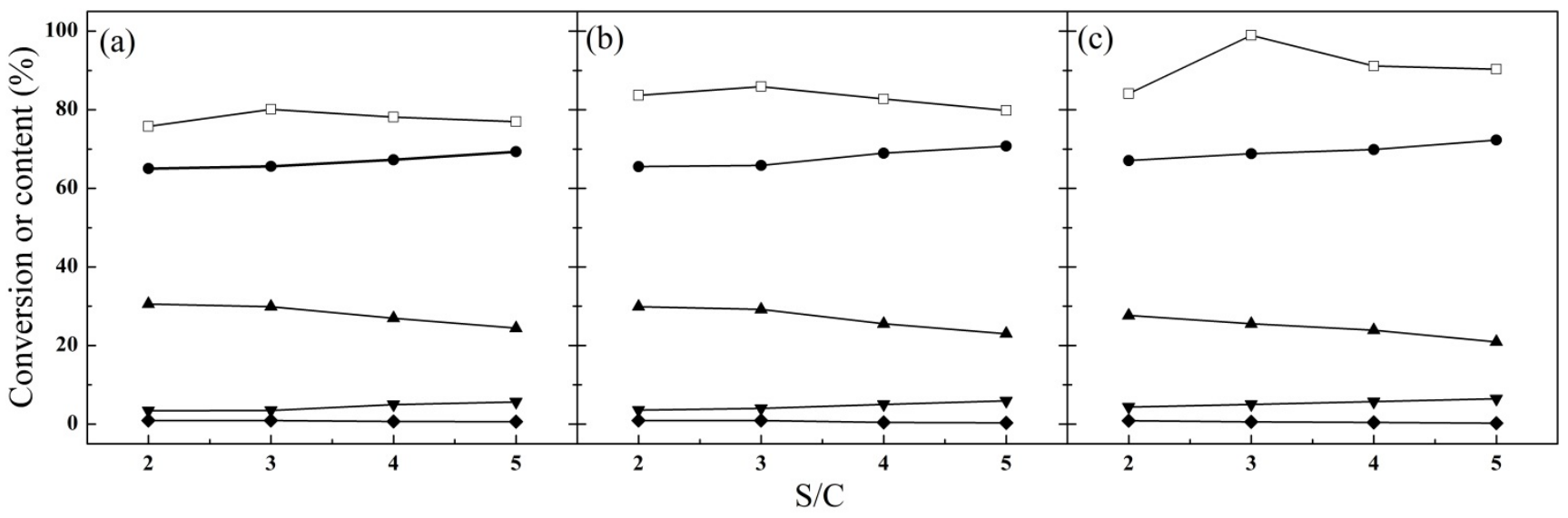

Various catalysts have been prepared for steam reforming of toluene in previous studies. The catalytic performances of those previously reported catalysts (No.1-7) and our $\mathrm{Ni}-\mathrm{CeO}_{2}(3 \mathrm{wt} \%) / \mathrm{SBA}-15$ catalyst (No.8) are given in Table 3. It is clear that the $\mathrm{Ni}-\mathrm{CeO}_{2} / \mathrm{SBA}-15$ is an effective catalyst with promising toluene conversion capability. 
Table 3. Comparison of the catalytic performances of previously reported catalysts and the $\mathrm{Ni}-\mathrm{CeO}_{2}(3 \mathrm{wt} \%) / \mathrm{SBA}-15$ catalyst.

\begin{tabular}{|c|c|c|c|c|c|c|}
\hline No. & Catalyst & Temperature $\left({ }^{\circ} \mathrm{C}\right)$ & $\mathrm{S} / \mathrm{C}$ & Space time & Toluene conversion $(\%)$ & Ref. \\
\hline 1 & $\mathrm{Fe} / \mathrm{MgO}$ & 850 & $18: 7$ & $20 \mathrm{~kg}_{\mathrm{cat}} \mathrm{h} / \mathrm{m}^{3[\mathrm{a}]}$ & 77 & {$[36]$} \\
\hline 2 & $\mathrm{NiO}-\mathrm{CeO}_{2} /$ Olivine & 830 & $5: 1$ & $862 \mathrm{~h}^{-1[b]}$ & 77.9 & {$[20]$} \\
\hline 3 & Fe/Olivine & 850 & $15: 7$ & $16.7 \mathrm{~kg}_{\mathrm{cat}} \mathrm{h} / \mathrm{m}^{3[\mathrm{a}]}$ & 85 & [29] \\
\hline 4 & $\mathrm{Ni} /$ cordierite & 900 & $2: 1$ & - & 94.1 & [19] \\
\hline 5 & $\mathrm{Ni} / \mathrm{Al} / \mathrm{La}$ & 650 & $5.7: 1$ & $1326 \mathrm{~h}^{-1[\mathrm{c}]}$ & 94.53 & [37] \\
\hline 6 & Cordierite & 900 & $1.5: 1$ & $1031 \mathrm{~h}^{-1[\mathrm{~b}]}$ & 95 & [38] \\
\hline 7 & $\mathrm{Ni} /$ Olivine & 650 & $2.3: 1$ & $9 \mathrm{~kg}_{\text {cat }} \mathrm{h} / \mathrm{m}^{3[\mathrm{a}]}$ & 100 & [39] \\
\hline 8 & $\mathrm{Ni}-\mathrm{CeO}_{2} / \mathrm{SBA}-15$ & 850 & $3: 1$ & $16 \mathrm{~kg}_{\text {cat }} \mathrm{h} / \mathrm{m}^{3[\mathrm{a}]}$ & 98.9 & - \\
\hline
\end{tabular}

\subsection{Catalytic Stability Test}

Experiments were also conducted to evaluate the catalytic stability of the $\mathrm{Ni}-\mathrm{CeO}_{2}(3 \mathrm{wt} \%) / \mathrm{SBA}-15$ catalyst at the $\mathrm{S} / \mathrm{C}$ ratio of 3 and catalytic temperature of $850{ }^{\circ} \mathrm{C}$, which were the best catalyst and reaction condition for toluene conversion. The catalytic stability test lasted for $29 \mathrm{~h}$, and the results are

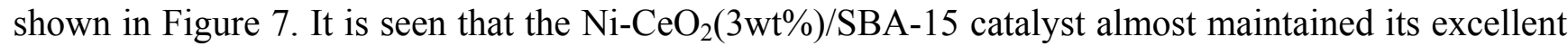
catalytic activity, and the toluene conversion was only slightly reduced during the whole test. This might be due to the small amount of coke deposition on the quartz reactor (not on the catalyst), which was observed after the stability test. Meanwhile, the contents of $\mathrm{H}_{2}$ and $\mathrm{CO}_{2}$ were increased very slightly, while the contents of $\mathrm{CO}$ and $\mathrm{CH}_{4}$ dropped only a little. The carbon content of the used catalyst was only $0.01 \mathrm{wt} \%$, which was negligible. The above results clearly indicated that the $\mathrm{Ni}-\mathrm{CeO}_{2}(3 \mathrm{wt} \%) / \mathrm{SBA}-15$ catalyst possessed promising anti-coke deposition performance and catalytic stability.

Figure 7. Catalytic stability test for steam reforming of toluene using $\mathrm{Ni}-\mathrm{CeO}_{2}(3 \mathrm{wt} \%) / \mathrm{SBA}-15$ catalyst. ( $\left.\square\right)$ toluene conversion; (०) $\mathrm{H}_{2}$ content; $(\Delta) \mathrm{CO}$ content; $(\nabla) \mathrm{CO}_{2}$ content; and $(\diamond) \mathrm{CH}_{4}$ content.

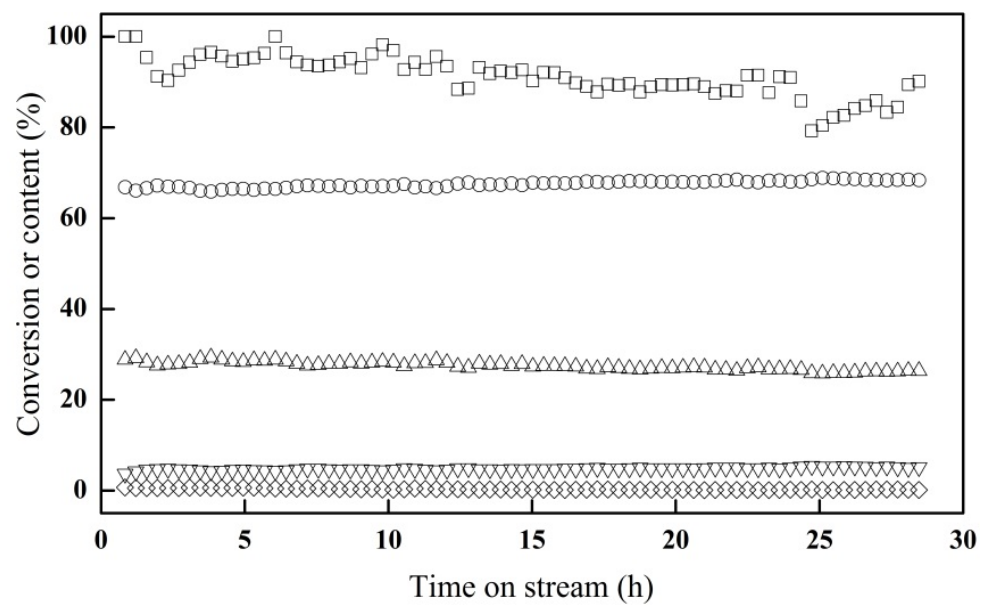




\section{Conclusions}

In this study, $\mathrm{Ni}-\mathrm{CeO}_{2} / \mathrm{SBA}-15$ catalysts were prepared for steam reforming of toluene, and they exhibited promising capabilities on the toluene conversion, anti-coke deposition as well as catalytic stability. During the catalytic steam reforming process, the toluene conversion was steadily enhanced with the increase of the catalytic temperature and the $\mathrm{CeO}_{2}$ loading content. Moreover, the toluene conversion was firstly increased and then decreased along with the $\mathrm{S} / \mathrm{C}$ ratio, with the maximal value obtained at the $\mathrm{S} / \mathrm{C}$ ratio of 3 . The $\mathrm{Ni}-\mathrm{CeO}_{2}(3 \mathrm{wt} \%) / \mathrm{SBA}-15$ catalyst possessed the best catalytic activity, with the maximal toluene conversion as high as $98.9 \%$ at the catalytic temperature of $850{ }^{\circ} \mathrm{C}$ and $\mathrm{S} / \mathrm{C}$ ratio of 3 . Moreover, this catalyst also showed promising catalytic stability during the long period stability test, and negligible coke formation was detected on the used catalyst. The gas products from the steam reforming process were mainly $\mathrm{H}_{2}$ and $\mathrm{CO}$, together with a little of $\mathrm{CO}_{2}$ and $\mathrm{CH}_{4}$. The $\mathrm{H}_{2}$ content in the gas products would be gradually decreased with the increase of the catalytic temperature, while the CO content would be gradually increased.

\section{Acknowledgments}

The authors thank the National Natural Science Foundation of China (51276062, 51106052), National Key Technology R\&D Program (2012BAD30B01), Program for New Century Excellent Talents in University (NCET-10-0374), 111 Project (B12034), and Fundamental Research Funds for the Central Universities (11ZG08, 12ZP02, 13ZP02) for financial support.

\section{Conflict of Interest}

The authors declare no conflict of interest.

\section{References}

1. Ball, M.; Wietschel, M. The future of hydrogen-opportunities and challenges. Int. J. Hydrog. Energy 2009, 34, 615-627.

2. Haykiri-Acma, H.; Yaman, S. Thermogravimetric investigation on the thermal reactivity of biomass during slow pyrolysis. Int. J. Green Energy 2009, 6, 333-342.

3. Gezer, I.; Doğru, M.; Akay, G. Gasification of apricot pit shells in a downdraft gasifier. Int. J. Green Energy 2009, 6, 218-227.

4. Yin, R.; Liu, R.; Wu, J.; Wu, X.; Sun, C.; Wu, C. Influence of particle size on performance of a pilot-scale fixed-bed gasification system. Bioresour. Technol. 2012, 119, 15-21.

5. Nguyen, T.D.B.; Ngo, S.I.; Lim, Y.-I.; Lee, J.W.; Lee, U.-D.; Song, B.-H. Three-stage steady-state model for biomass gasification in a dual circulating fluidized-bed. Energy Convers. Manag. 2012, 54, 100-112.

6. Huang, B.-S.; Chen, H.-Y.; Kuo, J.-H.; Chang, C.-H.; Wey, M.-Y. Catalytic upgrading of syngas from fluidized bed air gasification of sawdust. Bioresour. Technol. 2012, 110, 670-675.

7. Wang, L.; Hisada, Y.; Koike, M.; Li, D.; Watanabe, H.; Nakagawa, Y.; Tomishige, K. Catalyst property of Co-Fe alloy particles in the steam reforming of biomass tar and toluene. Appl. Catal. B Environ. 2012, 121-122, 95-104. 
8. Yang, X.Q.; Xu, S.P.; Xu, H.L.; Liu, X.D.; Liu, C.H. Nickel supported on modified olivine catalysts for steam reforming of biomass gasification tar. Catal. Commun. 2010, 11, 383-386.

9. Devi, L.; Ptasinski, K.J.; Janssen, F.J.J.G. Pretreated olivine as tar removal catalyst for biomass gasifiers: Investigation using naphthalene as model biomass tar. Fuel Process. Technol. 2005, 86, 707-730.

10. Yu, Q.Z.; Brage, C.; Nordgreen, T.; Sjöström, K. Effects of Chinese dolomites on tar cracking in gasification of birch. Fuel 2009, 88, 1922-1926.

11. Devi, L.; Ptasinski, K.J.; Janssen, F.J.J.G.; van Paasen, S.V.B.; Bergman, P.C.A.; Kiel, J.H.A. Catalytic decomposition of biomass tars: Use of dolomite and untreated olivine. Renew. Energy 2005, 30, 565-587.

12. Park, H.J.; Park, S.H.; Sohn, J.M.; Park, J.; Jeon, J.-K.; Kim, S.-S.; Park, Y.-K. Steam reforming of biomass gasification tar using benzene as a model compound over various Ni supported metal oxide catalysts. Bioresour. Technol. 2010, 101, S101-S103.

13. Li, C.S.; Hirabayashi, D.; Suzuki, K. Steam reforming of biomass tar producing $\mathrm{H}_{2}$-rich gases over Ni/MgO ${ }_{\mathrm{x}} / \mathrm{CaO}_{1-\mathrm{x}}$ catalyst. Bioresour. Technol. 2010, 101, S97-S100.

14. Zhao, Z.K.; Kuhn, J.N.; Felix, L.G.; Slimane, R.B.; Choi, C.W.; Ozkan, U.S. Thermally impregnated Ni-olivine catalysts for tar removal by steam reforming in biomass gasifiers. Ind. Eng. Chem. Res. 2008, 47, 717-723.

15. Colby, J.L.; Wang, T.; Schmidt, L.D. Steam reforming of benzene as a model for biomass-derived syngas tars over rh-based catalysts. Energy Fuel 2009, 24, 1341-1346.

16. Li, C.; Hirabayashi, D.; Suzuki, K. Development of new nickel based catalyst for biomass tar steam reforming producing $\mathrm{H}_{2}$-rich syngas. Fuel Process. Technol. 2009, 90, 790-796.

17. Łamacz, A.; Krztoń, A.; Djéga-Mariadassou, G. Steam reforming of model gasification tars compounds on nickel based ceria-zirconia catalysts. Catal. Today 2011, 176, 347-351.

18. Yan, C.-F.; Cheng, F.-F.; Hu, R.-R. Hydrogen production from catalytic steam reforming of bio-oil aqueous fraction over $\mathrm{Ni} / \mathrm{CeO}_{2}-\mathrm{ZrO}_{2}$ catalysts. Int. J. Hydrog. Energy 2010, 35, 11693-11699.

19. Zhao, B.F.; Zhang, X.D.; Chen, L.; Qu, R.B.; Meng, G.F.; Yi, X.L.; Sun, L. Steam reforming of toluene as model compound of biomass pyrolysis tar for hydrogen. Biomass Bioenergy 2010, 34, $140-144$.

20. Zhang, R.Q.; Wang, Y.C.; Brown, R.C. Steam reforming of tar compounds over Ni/olivine catalysts doped with $\mathrm{CeO}_{2}$. Energ. Convers. Manag. 2007, 48, 68-77.

21. Zhao, D.; Feng, J.; Huo, Q.; Melosh, N.; Fredrickson, G.H.; Chmelka, B.F.; Stucky, G.D. Triblock copolymer syntheses of mesoporous silica with periodic 50 to 300 angstrom pores. Science 1998, 279, 548-552.

22. Zhao, D.; Huo, Q.; Feng, J.; Chmelka, B.F.; Stucky, G.D. Nonionic triblock and star diblock copolymer and oligomeric surfactant syntheses of highly ordered, hydrothermally stable, mesoporous silica structures. J. Am. Chem. Soc. 1998, 120, 6024-6036.

23. Zhao, D.; Sun, J.; Li, Q.; Stucky, G.D. Morphological control of highly ordered mesoporous silica SBA-15. Chem. Mater. 2000, 12, 275-279.

24. Huang, B.; Li, X.; Ji, S.; Lang, B.; Habimana, F.; Li, C. Effect of MgO promoter on Ni-based SBA-15 catalysts for combined steam and carbon dioxide reforming of methane. J. Nat. Gas. Chem. 2008, 17, 225-231. 
25. Wan, H.; Li, X.; Ji, S.; Huang, B.; Wang, K.; Li, C. Effect of Ni loading and $\mathrm{Ce}_{\mathrm{x}} \mathrm{Zr}_{1-\mathrm{x}} \mathrm{O}_{2}$ promoter on Ni-Based SBA-15 catalysts for steam reforming of methane. J. Nat. Gas. Chem. 2007, 16, 139-147.

26. Li, D.; Nakagawa, Y.; Tomishige, K. Development of Ni-based catalysts for steam reforming of tar derived from biomass pyrolysis. Chin. J. Catal. 2012, 33, 583-594.

27. Bartholomew, C.H.; Farrauto, R.J. Chemistry of nickel-alumina catalysts. J. Catal. 1976, 45, 41-53.

28. Brown, M.D.; Baker, E.G.; Mudge, L.K. Environmental design considerations for thermochemical biomass energy. Biomass 1986, 11, 255-270.

29. Virginie, M.; Courson, C.; Kiennemann, A. Toluene steam reforming as tar model molecule produced during biomass gasification with an iron/olivine catalyst. Cr. Chim. 2010, 13, 1319-1325.

30. Jiménez-Morales, I.; Vila, F.; Mariscal, R.; Jiménez-López, A. Hydrogenolysis of glycerol to obtain 1,2-propanediol on Ce-promoted Ni/SBA-15 catalysts. Appl. Catal. B 2012, 117-118, 253-259.

31. Wang, K.; Li, X.; Ji, S.; Shi, X.; Tang, J. Effect of $\mathrm{Ce}_{\mathrm{x}} \mathrm{Zr}_{1-\mathrm{x}} \mathrm{O}_{2}$ promoter on Ni-based SBA-15 catalyst for steam reforming of methane. Energy Fuel 2008, 23, 25-31.

32. Solsona, B.; Blasco, T.; López Nieto, J.M.; Peña, M.L.; Rey, F.; Vidal-Moya, A. Vanadium oxide supported on mesoporous MCM-41 as selective catalysts in the oxidative dehydrogenation of alkanes. J. Catal. 2001, 203, 443-452.

33. Vradman, L.; Landau, M.V.; Herskowitz, M.; Ezersky, V.; Talianker, M.; Nikitenko, S.; Koltypin, Y.; Gedanken, A. High loading of short WS2 slabs inside SBA-15: Promotion with nickel and performance in hydrodesulfurization and hydrogenation. J. Catal. 2003, 213, 163-175.

34. $\mathrm{Hu}, \mathrm{X}$; $\mathrm{Lu}, \mathrm{G}$. Investigation of steam reforming of acetic acid to hydrogen over $\mathrm{Ni}-\mathrm{Co}$ metal catalyst. J. Mol. Catal. A 2007, 261, 43-48.

35. Zhang, B.; Tang, X.; Li, Y.; Cai, W.; Xu, Y.; Shen, W. Steam reforming of bio-ethanol for the production of hydrogen over ceria-supported Co, Ir and Ni catalysts. Catal. Commun. 2006, 7 , 367-372.

36. Di Felice, L.; Courson, C.; Foscolo, P.U.; Kiennemann, A. Iron and nickel doped alkaline-earth catalysts for biomass gasification with simultaneous tar reformation and $\mathrm{CO}_{2}$ capture. Int. J. Hydrog. Energy 2011, 36, 5296-5310.

37. Bona, S.; Guillén, P.; Alcalde, J.G.; García, L.; Bilbao, R. Toluene steam reforming using coprecipitated $\mathrm{Ni} / \mathrm{Al}$ catalysts modified with lanthanum or cobalt. Chem. Eng. J. 2008, 137, 587-597.

38. Xu, X.; Chen, L.; Zhang, X.; Sun, H.; Xu, M. Catalytic conversion of model compounds of biomass tar. J. Fuel Chem. Technol. 2009, doi:10.3969/j.issn.0253-2409.2009.02.023.

39. Świerczyński, D.; Libs, S.; Courson, C.; Kiennemann, A. Steam reforming of tar from a biomass gasification process over Ni/olivine catalyst using toluene as a model compound. Appl. Catal. B 2007, 74, 211-222.

(C) 2013 by the authors; licensee MDPI, Basel, Switzerland. This article is an open access article distributed under the terms and conditions of the Creative Commons Attribution license (http://creativecommons.org/licenses/by/3.0/). 